\title{
Evaluation of sweet sorghum and sudangrass varieties by the viewpoint of bioethanol production
}

\author{
János Jóvér \\ University of Debrecen Center of Agricultural Sciences, \\ Research Institute of Karcag, Karcag \\ jover@agr.unideb.hu
}

SUMMARY

Bioenergy and biofuels are very important in today's energy policy. These kinds of energy resources have several advantages against fossil fuels. Environmental protection is a cardinal point of widespreading these technologies but the economic considerations are important as well. In order to improve the rate of the renewable energy in the energy consumption, the European Union settled down a program which determines a minimum ratio of renewable energy in the energy consumption for each member country of the EU. To fulfil the requirements bioenergy and biofuels should be produced. This production procedure needs adequate stocks which are commonly agricultural products.

One of the promising stocks is sorghum. This plant fits for bioethanol production due to its juice content being rich in sugar. In this study six sweet sorghum hybrids, two sudangrass hybrids and a sudangrass variety have been evaluated to determine their theorical ethanol production capacity.

On the score of the results of the year 2009 it can be set that sudangrasses have a lower theorical ethanol capacity than sweet sorghums have. In the case of sweet sorghums 1860.29-2615.47 l ha-1 ethanol yields had been calculated, while the sudangrasses had only 622.96$801.03 \mathrm{l} \mathrm{ha}^{-1}$. After that throughout three years (2011-2013) the sweet sorghum hybrids have been evaluated in order to determine the fluctuations of the ethanol production capacity caused by the impact of the years. As a result 2425.44-4043.6 l ha - $^{-1}$ theorical ethanol capacities have been calculated, which means that sweet sorghums can be an adequate stock to produce bioethanol.

Keywords: biofuel, bioethanol, sweet sorghum, sudangrass, Brix ${ }^{\circ}$

\section{ÖSSZEFOGLALÁS}

A bioenergia és a biohajtóanyagok nagyon fontosak napjaink energiapolitikájában. Ezen energiaforrások számos elönnyel birrnak a foszszilis eredetü hajtóanyagokkal szemben. A környezetvédelem egy meghatározó pont e technológiák terjesztésében, de a gazdasági szempontok sem elhanyagolhatóak. A megújuló energiaforrások energiafelhasználásban való részarányának növelésére az Európai Unió kidolgozott egy programot, amely egy minimum részarányt határoz meg a megújuló energiák számára a teljes energiafogyasztás tekintetében minden EU tagállam számára. Ahhoz, hogy az elöirásoknak eleget tegyünk, a bioenergia és a biohajtóanyagok elöállitása mindenképp szükséges. Ezekhez az elöállitási folyamatokhoz megfelelö alapanyagok szükségesek, amelyek rendszerint mezögazdasági termékek.

Egy ígéretes alapanyag a cirok. Cukorban gazdag létartalmának köszönhetően ez a növény alkalmas lehet a bioetanol elöállitására. Ebben a tanulmányban hat cukorcirok hibrid, kettö szudánifü hibrid és egy szudánifü fajta elméleti bioetanol hozama került meghatározásra.

A 2009-es év eredményei alapján a szudánifü alacsonyabb elméleti bioetanol hozammal bir, mint a cukorcirok. A cukorcirkok esetében 1860,29-2615,47 l/ha etanol hozamok kerületek meghatározásra, míg a szudánifüvek esetében ez az érték csak 622,96-801,03 l/ha között alakult. Ezt követöen további három éven keresztül (2011-2013) vizsgáltam a cukorcirok hibrideket, az elméleti bioetanol hozamok évjárathatás következtében jelentkezö fluktuációinak meghatározására. A vizsgálatok eredményeképpen 2425,44-4043,6 l/ha elméleti etanol hozam került meghatározásra, ami azt jelenti, hogy a cukorcirok egy megfelelö alapanyaga lehet a bioetanol elöállításának.

Kulcsszavak: biohajtóanyag, bioetanol, cukorcirok, szudánifü, Brixº

\section{INTRODUCTION}

Plant biomass known as a promising energy resource which can be the base of biofuel production and has a lower emission of greenhouse gases (Berndes et al., 2003; Antonopoulou et al., 2008). Furthermore, bioenergy can stabilize the farmers' incomes, and can maintain and improve the ecological and social sustainability (Parikka, 2004; Xiong et al., 2008).

Bioethanol and other biofuels, approached by the viewpoint of environmental protection, are more environmental friendly than fossil fuel technologies, because these kinds of fuels are relatively carbon neutral (Tillman et al., 2006), during the production process hazardous compounds do not appear and the transport of fuels can be reduced (Drapcho et al., 2008). Moreover the emission of toxic exhaust and greenhouse gases can be decreased (Nguyen and $\mathrm{Li}$, 1991; Zhang et al., 2003).

Another important consideration is the fact that before 2004 the European Union had less than 1\% of the world's oil resources, while $20 \%$ of these oil resources were used in the EU countries (Vajda, 2004), therefore besides the environmental protection the economics and the energy-policy are very important in this field as well. The European Union had enacted a program to promote the consumption of biofuels by setting minimum targets in fuel substitution for the member countries of the EU. According to the 2009/28/EC Directive the European Union would like to increase the use of bioenergy and biofuels, therefore $20 \%$ of the energy consumption and $10 \%$ of the fuel consumption should come from renewable resources in Hungary. 
Ethanol is mostly produced from sugar and starch. Lignocellulose as feedstock for ethanol production will be used in the very near future (Hamelink et al., 2005), as the processing technology turns economical. Sweet sorghum has therefore been considered as a potentially important feedstock for bioethanol production (Lynd et al., 1991; Mamma et al., 1995; Buxton et al., 1999; Liu et al., 2008).

Nowadays bioethanol production is based on mostly maize and sugarcane (Berg, 2004; RFA, 2010), but due to the agrononomic flexibility and productivity, sweet sorghum can be a viable option in some regions of the world (Blaskó et al., 2008; Daliva-Gomez et al., 2011). The juice extracted from the sweet sorghum's stem contains approximately 16-18\% different kinds of sugar mostly sucrose, glucose and fructose (Goshadrou et al., 2011). According to Kovács et al. (2011) the sweet sorghum's ethanol production capacity is between $10001 \mathrm{ha}^{-1}$ and $50001 \mathrm{ha}^{-1}$ while according to Mojovic et al. (2009) this value is $13651 \mathrm{ha}^{-1}$.

In this study sweet sorghum varieties have been evaluated to determine the differences among the varieties in the bioethanol production capacity caused by the genetic variability. During the research four vegetation periods were studied in order to appoint the influential impacts of the climatic conditions.

\section{MATERIAL AND METHODS}

The researches of the energetic use of sorghum in the Research Institute of Karcag started more than thirty years ago (Kapocsi et al., 1983). The goal of these researches is to determine the potential role of these plants in the biomass energy. In this survey six sweet sorghum hybrids, two sudangrass hybrids and a sudangrass variety have been studied. The experiment was made with nine varieties and they were sown on meadow soil at Karcag in 2009. Later the experiment was continued with six hybrids for three years in the period of 2011-2013.

The climatic conditions in the evaluated years were quite variable. The average precipitation in 2011 and 2012 was 385.7 and $344.5 \mathrm{~mm}$, which differs from the fifty years' average value of precipitation $(503.3 \mathrm{~mm})$. The annual average temperatures also differ from the fifty years' average value of annual temperature $\left(10.0^{\circ} \mathrm{C}\right)$ (Table 1).

During the experiment samples were took from $1 \mathrm{~m}^{2}$ by different intervals of time in the period of AugustNovember. The weight of stems in the samples, the water content of the stems and the refractive dry matter content have been determined. The refractive dry matter content, which is in a strict correlation with the sugar content (Liu et al., 2008; Kawahigashi et al., 2013), has been measured by refractometer (Figure 1).

Table 1.

Temperature and precipitation data in Karcag

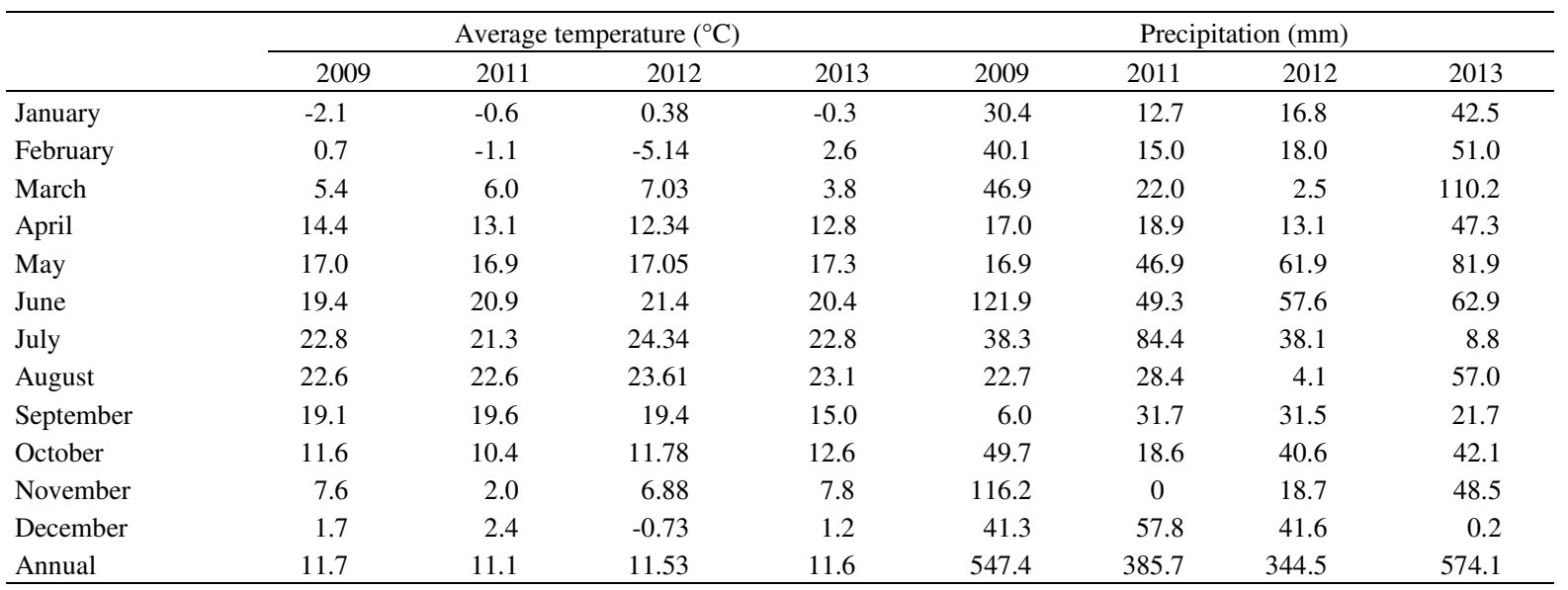

Source: Research Institute of Karcag

Figure 1: Digital refractometer in use

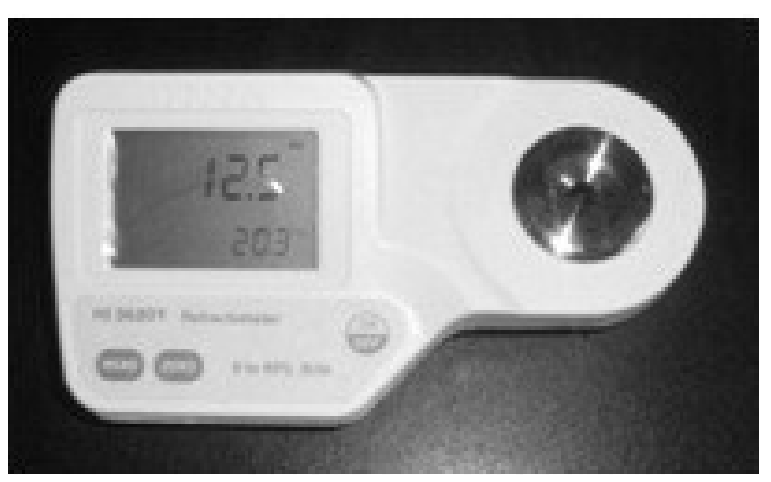

On the basis of the measured data the differences among the varieties have been investigated by ANOVA (R Core Team, 2010). After it the theorical bioethanol production capacities have been calculated for each variety. In the calculations $90 \%$ sugar content of the refractometric dry matter content and $85 \%$ fermentation efficiency were assumed.

\section{RESULTS}

By right of the data measured in 2009 the theorical bioethanol production has been calculated for each variety (Table 2-3). The results denoted that sudangrasses have lower pontetial in bioethanol production. Sudangrasses 
reached only 622.96-801.03 $1 \mathrm{ha}^{-1}$ average ethanol capacity with a low standard deviation $(\mathrm{p}=0.05)$, and relatively small range $181.95-779.95 \mathrm{l} \mathrm{ha}^{-1}$. In the case of sweet sorghums the situation was different. These plants have provided 1860.29-2615.74 $1 \mathrm{ha}^{-1}$ average ethanol potential, with a bit higher standard deviation and range.

Table 2

The main statistical data of the sweet sorghum hybrids' bioethanol production capacity in $2009\left(\mathrm{l} \mathrm{ha}^{-1}\right)$

\begin{tabular}{lrcrr}
\hline \multicolumn{1}{c}{ Hybrid } & Mean & $\begin{array}{c}\text { Standard } \\
\text { Deviation }\end{array}$ & Variance & Range \\
\hline Berény & 2106.09 & 637.26 & 406104.4 & 1460.53 \\
Róna1 & 1860.29 & 562.93 & 316892.1 & 1274.40 \\
Monori édes & 2246.68 & 860.71 & 74819.8 & 1927.44 \\
Cellu & 2615.74 & 569.53 & 324367.3 & 1180.76 \\
Sucrosorgo & 2275.28 & 174.77 & 30543.86 & 377.49 \\
G1990 & 2062.56 & 672.34 & 452045.9 & 1464.44 \\
\hline
\end{tabular}

The main statistical data of the sudangrass varieties' bioethanol production capacity in $2009\left(1 \mathrm{ha}^{-1}\right)$

\begin{tabular}{lcccc}
\hline \multicolumn{1}{c}{ Hybrid } & Mean & $\begin{array}{c}\text { Standard } \\
\text { Deviation }\end{array}$ & Variance & Range \\
\hline Bovital & 801.03 & 87.65 & 7682.62 & 181.95 \\
Gardavan & 762.80 & 346.46 & 120035.1 & 779.95 \\
KST1011 & 622.96 & 194.04 & 37652.39 & 428.77 \\
\hline
\end{tabular}

After 2009 the research was confined to sweet sorghum. In the years of 2011-2013 the weight of stems of $1 \mathrm{~m}^{2}$, the water content of the stems and the refractometric dry matter content were measured. On the score of three years data the influential impacts of the years' climatic conditions can be eliminated, which was the base of the statistical analysis.

In the period of August-November the average refractometric dry matter content was the highest generally in October (Figure 2). In some sampling dates the standard deviations are very high which is caused by the climatic differences of the years. In the case of some hybrids like Berény the changes of the refractometric dry matter content is a bell-shaped curve, while in other hybrids like Sucrosorgo these data show a growing graph, which is coherent with the length of the hybrid's vegetation period.

The maximum of the refractometric dry matter content was in October in every case, thus the data of yield, water content and refractometric dry matter content measured in October of every year, were analyzed in ANOVA to determine the less significant difference of the hybrids by the investigated aspects.

According to the results there are significant differences of the hybrids by the viewpoints above (Table 4). Hybrids with the same letters are in the same group by the evaluated aspect.

Figure 2: The average refractometric dry matter contents $\left(\mathrm{Brix}^{\circ}\right)$ and their standard deviations in the case of the investigated hybrids (2011-2013)
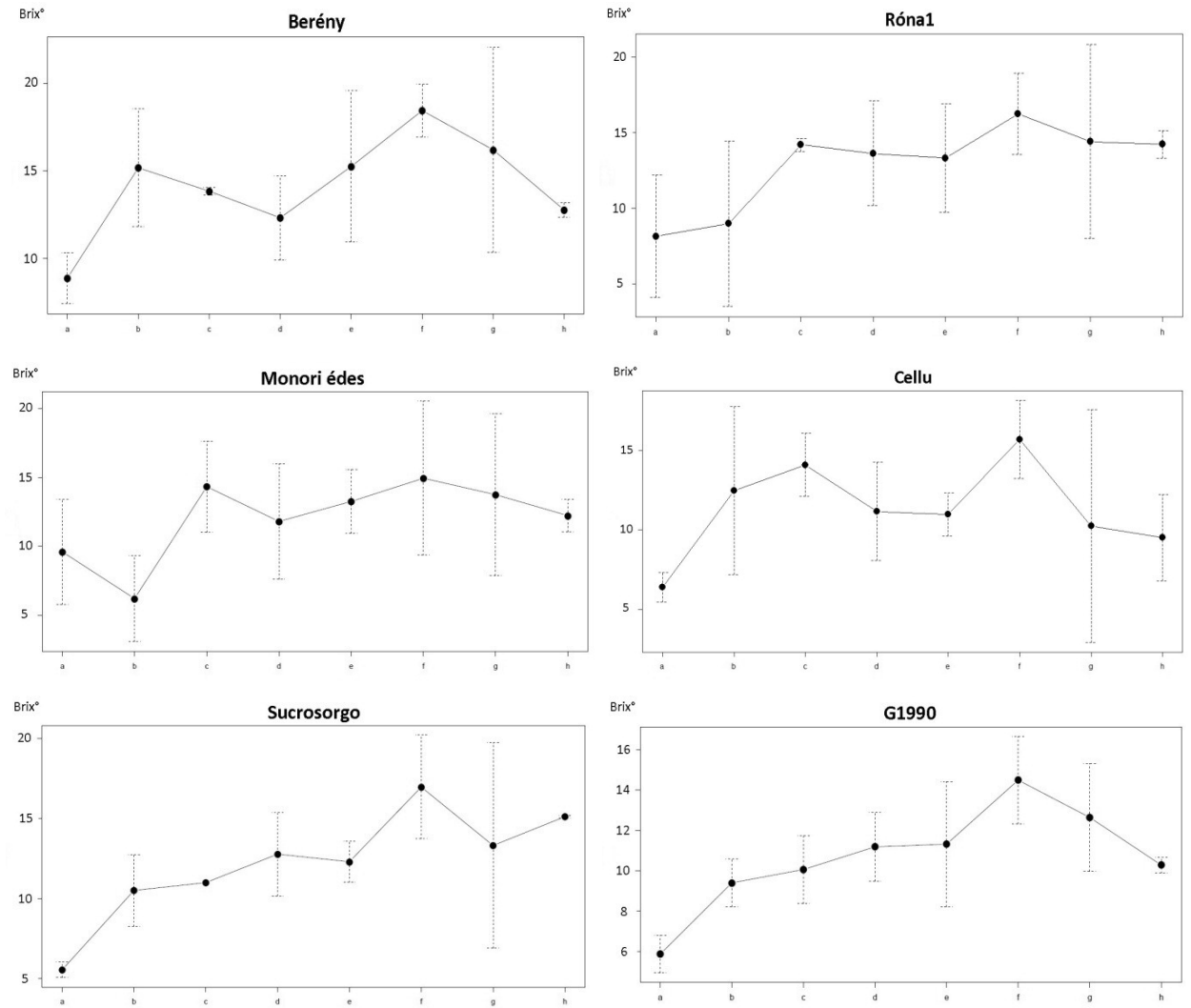

Note: sampling date - a: the end of august, b: the beginning of September, c: the middle of September, d: the end of September, e: the beginning of October, f: the middle of October, g: the end of October, h: the beginning of November. 
The comparison of the sweet sorghum hybrids by the measured data

\begin{tabular}{|c|c|c|c|c|c|c|}
\hline \multirow{2}{*}{ Hybrid } & \multicolumn{2}{|c|}{ Yield of stem $\left(\mathrm{kg} \mathrm{m}^{-2}\right)$} & \multicolumn{2}{|c|}{ Water content $(\mathrm{m} / \mathrm{m} \%)$} & \multicolumn{2}{|c|}{$\mathrm{Rdm}^{*}$ content $\left(\mathrm{Brix}^{\circ}\right)$} \\
\hline & group & mean & group & mean & group & mean \\
\hline Berény & $\mathrm{bc}$ & 5.420 & $\mathrm{c}$ & 66.62 & $\mathrm{a}$ & 16.29 \\
\hline Róna1 & $\mathrm{c}$ & 3.856 & $\mathrm{a}$ & 73.92 & $a b$ & 14.08 \\
\hline Monori édes & $\mathrm{c}$ & 4.645 & $\mathrm{a}$ & 75.38 & $a b$ & 13.81 \\
\hline Cellu & $a b$ & 6.473 & $\mathrm{a}$ & 74.46 & $\mathrm{~b}$ & 13.70 \\
\hline Sucrosorgho & $\mathrm{a}$ & 7.231 & $\mathrm{bc}$ & 67.54 & $a b$ & 12.46 \\
\hline G1990 & $a b$ & 6.523 & $a b$ & 71.38 & $\mathrm{~b}$ & 11.84 \\
\hline $\mathrm{LSD}_{5 \%}$ & \multicolumn{2}{|c|}{1.65} & \multicolumn{2}{|c|}{4.10} & \multicolumn{2}{|c|}{3.18} \\
\hline
\end{tabular}

*Refractometric drymatter

The average bioethanol potential of the hybrids' was between 2425.44-4043.60 $1 \mathrm{ha}^{-1}$ which absolutely expresses the differences. The average Rdm content was the highest in Berény, but the Sucrosorgo had a higher average yield, thus the ethanol potential is higher in this case (Table 5).
In the sweet sorghum based bioethanol production the sugar content and the yield of stem are very important, because these parameters are decisive in the bioethanol production. The differences of these parameters caused by genetic variability can determine the capability of a variety for biofuel production.

The main calculated data of the sweet sorghum hybrids' bioethanol potential (2011-2013)

\begin{tabular}{|c|c|c|c|c|c|c|}
\hline & Berény & Róna1 & Monori édes & Cellu & Sucrosorgo & G1990 \\
\hline Yield of stem $\left(\mathrm{kg} \mathrm{m}^{-2}\right)$ & 5.42 & 3.856 & 4.645 & 6.473 & 7.231 & 6.523 \\
\hline Water content $(\%)$ & 66.62 & 73.92 & 75.38 & 74.46 & 67.54 & 71.38 \\
\hline $\operatorname{Rdm}$ content $\left(\right.$ Brix $\left.^{\circ}\right)$ & 16.29 & 14.08 & 13.81 & 11.84 & 13.70 & 12.46 \\
\hline Sugar content $\left(\mathrm{g} \mathrm{m}^{-2}\right)$ & 529.38 & 361.20 & 435.19 & 513.60 & 602.17 & 522.14 \\
\hline Etanol production capacity $\left(1 \mathrm{ha}^{-1}\right)$ & 3554.79 & 2425.44 & 2922.30 & 3448.81 & 4043.60 & 3506.15 \\
\hline
\end{tabular}

\section{CONCLUSIONS}

Biofuels can be a very important part of the European Union's transportation. Therefore a program had been made up to increase the part of the renewable resources of the energy consumption. By the 2009/28/EC directive more emphasis will be put on the bioethanol production. This goal needs stocks that makes the principle of this survey. In this study sweet sorghum and sudangrass varieties had been evaluated to determine their suitability for bioethanol production. By the results it can be laid down that sudan grass may has a greater potential in other fields of bioenery (eg.: biogas), while sweet sorghum can be an adequate stock to produce bioethanol.

On the score of three years observation 2425.444043.6 1 ha $^{-1}$ theorical ethanol yield was calculated of the sorghum hybrids which make this plant a promising feedstock in the biofuel production. The different hybrids have different ethanol production capacity due to the genetic variability. The different sorghum genotypes adapt to the weather and other conditions (eg. agrotechnical factors) differently, but generally sweet sorghum hybrids are a competitive solution to produce the green fuel.

In Hungary mostly sweet sorghum hybrids with a medium-long vegetation period are grown, but in some cases the production of hybrids with longer vegetation period can be efficient. A sweet sorghum based bioethanol plant requires large sweet sorghum production sites. By using hybrids with different vegetation periods, the harvest season can be elongated which can effect advantages in the sugar yield.

\section{REFERENCES}

Antonopoulou, G.-Gavala, H. N.-Skiadas, I. V.-Angelopoulos, K.Lyberatos, G. (2008): Biofuels generation from sweet sorghum: fermentative hydrogen production and anaerobic digestion of the remaining biomass. Bioresource Technology. 99: 110-119. Berg, C. (2004): World Fuel Ethanol. Analysis and Outlook. Japan. Berndes, G.-Hoogwijk, M.-Broek, R. (2003): The contribution of biomass in the future global energy supply: a review of 17 studies. Biomass Bioenergy. 25: 1-28.

Blaskó, L.-Balogh, I.-Ábrahám, É. B. (2008): Possibilities of Sweet Sorghum production for ethanol on the Hungarian Plain. Cereal Res. Commun. 36. 1: 1251-1254.
Buxton, D. R.-Anderson, I. C.-Hallam, A. (1999): Performance of sweet and forage sorghum grown continuously, double-cropped with winter rye, or in rotation with soybean and maize. Agronomy Journal. 91: 93-101.

Daliva-Gomez, F. J.-Chuck-Hernandez, C.-Perez-Carillo, E.Rooney, W. L.-Serna-Saldivar, S. O. (2011): Evaluation of bioethanol production from five different varieties of sweet and forage sorghums (Sorghum bicolor L. Moench). Industrial Crops and Products. 33: 611-616. 
Directive 2009/28/EC of the European Parliament and of the Council of 23 April 2009 on the promotion of the use of energy from renewable sources and amending and subsequently repealing Directives 2001/77/EC and 2003/30/EC.

Drapcho, C. M.-Nhuan, N. P.-Walker, T. H. (2008): Biofuels Engineering Process Technology. The McGraw-Hill Companies Inc.

Goshadrou, A.-Karimi, K.-Taherzadeh, M. J. (2011): Bioethanol production from sweet sorghum bagasse by Mucor hiemailis. Ind. Crops Prod. 34: 1219-1225.

Hamelink, C. N.-Hooijdonk, G. V.-Faaij, A. P. C. (2005): Ethanol from lignocellulosic biomass: techno-economic performance in short-, middle- and long-term. Biomass Bioenergy. 28: 384-410.

Kapocsi I.-Lazányi J.-Kovács B. (1983): A cukorcirok törzsek és hibridkombinációk termőképességének vizsgálata hígtrágyával öntözött területen alkohol elöállítás céljából. Növénytermelés. 33. 4: 529-534.

Kawahigashi, H.-Kasuga, S.-Okuizumi, H.-Hiradate, S.-Yonemaru, J. (2013): Evaluation of Brix and sugar content in stem juice from sorghum varieties. Japanese Society of Grassland Science. Grassland Science. 59: 11-19.

Kovács G. P.-Mikó P.-Nagy L.-Gyuricza Cs. (2011): Talajművelési eljárások hatása a cukorcirok (Sorghum bicolor L. Moench) beltartalmi paramétereire. Növénytermelés. 60. 1: 61-68.

Liu, R.-Li, J.-Shen, F. (2008): Refining bioethanol from stalk juice of sweet sorghum by immobilized yeast fermentation. Renewable Energy. 33: 1130-1135.

Lynd, L. R.-Cushman, J. H.-Nichols, R. J.-Wyman, C. E. (1991): Fuel ethanol from cellulosic biomass. Science. 251: 1318-1323.
Mamma, D.-Christakopoulos, P.-Koullas, D.-Kekos, D.-Macris, B. J.Koukios, E. (1995): An alternative approach to the bioconversion of sweet sorghum carbohydrates to ethanol. Biomass Bioenergy. 8: 99-103.

Mojovic, L.-Pejin, D.--Grujic, O.-Markov, S.-Pejin, J.-Rankin, M. (2009): Progress in the production of bioethanol on starch based feedstocks. Chemical Industry and Chemical Engineering Quarterly. 15: 221-226.

Nguyen, M. H.-Li, R. G. H. (1991): Review of the present feasibility of crop based fuel alcohol production in Australia. Proceedings of the IX. internation symphosium on alcohol fuels. 3: 1040-1045.

Parikka, M. (2004): Global biomass fuel resources. Biomass Bioenergy. 27: 613-620.

R Core Team (2012): R: A language and environment for statistical computing. R Foundation for Statistical Computing. Vienna. Austria. http://www.R-project.org/.

R.F.A. (2010): The Industry-Statistics. http://www.ethanolfra.org

Tillman, D.-Hill, J.-Lehman, C. (2006): Carbon-negtive biofuels from low input high-diversity grassland biomass. Science. 314 : 1598-1600.

Vajda Gy. (2004): Energiaellátás ma és holnap. Folpress Nyomdaipari Kft. Budapest. 387.

Xiong, S.-Zhang, Q.-Zhang, D.-Olsson, R. (2008): Influence of harvest time on fuel characteristics of five potential energy crops in northern China. Bioresource Technology. 99: 479-485.

Zhang, C.-Wei, J.-Jing, X. (2003): Life cycle economic analysis of fuel ethanol derived from cassava in southwest China. Renewable Sustainable Energy. 7: 353-366. 
